Review Article

\title{
NOVEL NANO THERAPEUTIC MATERIALS FOR THE EFFECTIVE TREATMENT OF RHEUMATOID ARTHRITIS-RECENT INSIGHTS
}

\author{
NARESH KUMAR AHUJA*, JITENDRA SINGH RAJAWAT
}

Bhupal Nobels University, Udaipur, Rajasthan, India

Email: nareshkahuja@gmail.com

Received: 09 May 2021, Revised and Accepted: 13 Sep 2021

\begin{abstract}
Recent advances in science and technology and greatly modified the way we stumble on, deal with and prevent special diseases in all components of human lifestyles. Rheumatoid arthritis (RA) is the most not unusual complex multifactorial joint related autoimmune, chronic, severe systemic inflammatory ailment with unknown etiology completed with increased cardiovascular risks. It is regularly associated with critical synovial joint inflammation, autoantibody production, cartilage/bone tissue destruction, cardiovascular, pulmonary, skeletal disorders and massive inflammatory infiltration which might in the end motive extreme disability, huge complications, premature mortality and decreased life quality. Pro-inflammatory cytokines like IL-1, IL-6, IL-8 and IL-10 were dependable for the induction of inflammation in RA patients. It has a global occurrence of around 1\% with the incidence among women being 2-3 times extra in men. Preclinical RA, genetic variables, and environmental factors have all been linked to the disease's etiology. Because there is no known cure for RA, the primary goal of treatment is to achieve the shortest possible illness duration and, if possible, rehabilitation. Current clinical remedies of RA display numerous drawbacks which include excessive doses, common administration, speedy metabolism, bad absorption, low responsiveness, higher cost and serious side consequences. These obstacles have inspired extremely good growth of the studies and to enhance those obstacles, nanoparticles that are able to encapsulating and protecting tablets from degradation earlier than they reach the target site in vivo, might also function drug delivery structures. Bioavailability and therapeutic bioactivity can be improved, and limited emphasis on damaged joints can be allowed. The current study provides a platform for different lipid nanoparticle methods for RA therapy, using the newly developing field of lipid nanoparticles to improve a targeted theranostic device for RA treatment. This review aims to present the most recent major application of lipid nanoparticles as a biocompatible and biodegradable transport device for improving RA concentration on over free drugs by presenting tissue-specific concentrated on of ligand-controlled drug release by modulating nanoparticle composition. Additionally, we also discuss the pivotal demanding situations to be addressed, as well as destiny views. Therefore, it is feasible to claim that nanoparticles will, within the near future, play a critical role in advanced treatment and affected person-particular cures for human diseases which include RA.
\end{abstract}

Keywords: Rheumatoid arthritis, Lipid nanoparticle, Inflammation, Drug delivery

(C) 2021 The Authors. Published by Innovare Academic Sciences Pvt Ltd. This is an open access article under the CC BY license (https://creativecommons.org/licenses/by/4.0/) DOI: https://dx.doi.org/10.22159/ijap.2021v13i6.42912. Journal homepage: https://innovareacademics.in/journals/index.php/ijap

\section{INTRODUCTION}

Rheumatoid arthritis (RA) is an infectious condition characterized by inflammation of the chronic joint ultimately leading to serious weakness and premature mortality [1]. RA causes chronic inflammation of the synovial membrane and as the condition progresses, this leads to degradation of the periarticular bone, deterioration of articular cartilage and irreversible deformities along with mania of extra-articular condition [2]. Diverse factors such as disease action, socioeconomic, educational status, body mass index, spirituality, age and gender affects RA patient's quality of life [3]. The global occurrence of RA has been predictable to be approximately $1 \%$ and the occurrence of RA in women is $2-3$ times higher than in men [4]. In India, the occurrence of RA ranges from 0.28 to $0.7 \%$, which is close to the occurrence in developed nations [5]. People of all age groups are affected by RA, but it is extra prevalent in the 30-50-year-old middle age population [6]. RA can impact any joint within the body (fig. 1). However, it mostly affects proximal interphalangeal, metacarpophalangeal and metatarsophalangeal joints of wrists and knees [7]. It has been noticed that wrist is the very most common affected site in RA There were also some variations in the occurrence of swelling and tenderness with tenderness occurring more in large joints such as the elbow, shoulder and knee, while swelling happens in small joints such as metacarphalangeal joints [8]. Gastrointestinal annoyance, renal malfunctioning and enlarged cardio vascular risk were also connected with RA [9]. RA development seems to be stronger for men's connected with cigarette smoking than women's. The incidence of RA is unrevealed, but it is supposed that the environmental factors may add to its development in hereditarily susceptible individuals [10]. The genetic components and environmental factors affect the various types of cells (including $\mathrm{B}$ cells, $\mathrm{T}$ cells, macrophages/ synoviocytes) have been identified as key regulators for RA immunological events over the years following immune response and studies [11]. The linkages between environmental factors and the genetics of patients is correlated with the development of RA. Coffee/alcohol consumption, oral contraceptive use, birth weight abnormalities and breast feeding were more significant environmental risk factors for RA development [12]. The number of RA-related symptoms is revealed in fig. 2 .
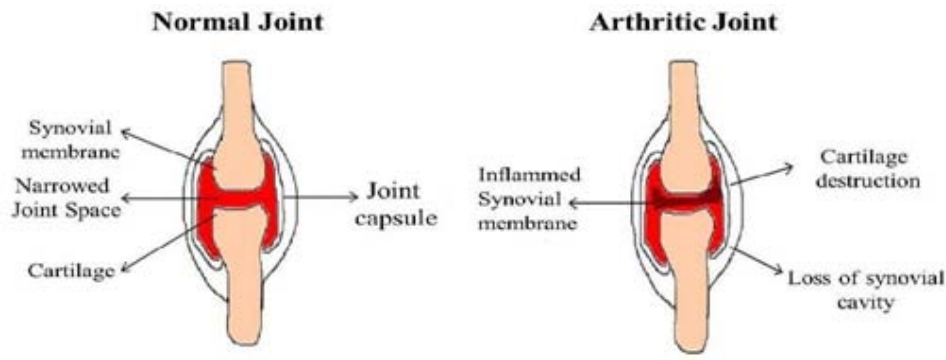

Fig. 1: Comparison between (A) normal and (B) rheumatoid arthritis joints [13] 


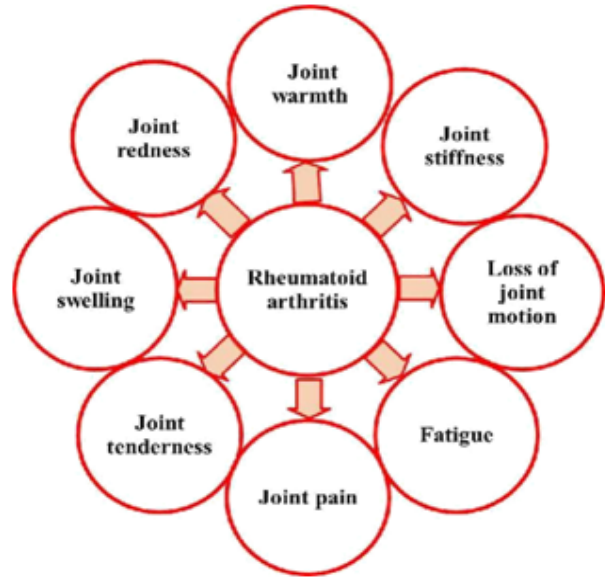

Fig. 2: Symptoms associated with rheumatoid arthritis development [13]

\section{Pathogenesis of RA}

Although the exact pathogenesis of RA is unknown, it has been reported that inflammatory mediators such as tumor necrosis factor-, C reactive protein, CD40 L, interleukins, monocyte chemoattractant protein-1, nuclear factor-B ligand receptor activator fractalkine, and metalloproteinase- 9 matrix, as well as adhesion molecules, play an important role in the disease's progression [14]. The several well-known variables involved in the pathogenesis of RA may be divided into three categories: preclinical RA, genetic factors, and environmental factors (fig. 3) [15-17]

\section{Preclinical RA}

In preclinical RA (the period prior to the development of arthritis), it has been reported that there is an enlarged level of disease-related biomarkers, including auto-antibodies in the body [18]. IgMRheumatoid factor, RA33, Sa, p68, calpastatin and perinuclear factor [1] are among the various disease-specific auto-antibodies. The rheumatoid factor (RF) plays an significant role in RA pathogenesis. The occurrence of RF is used as a serological criterion for the diagnosis of RA according to the American Rheumatism connection [19].

\section{Genetic factors}

RA expansion depends on the genetic background association and a number of environmental factors. Studies in molecular biology established the key role of major genes of the histocompatibility complex (MHC) in disease pathogenesis [20]. In RA, HLA-DRB1 gene was documented as one of the significant genetic associations in MHC, where sequences of shared epitopes within the DRB1 molecule are programmed by specific alles within the clusters DRB $1 * 04$ and * 01 [21]. Other genetic contributors to the pathogenesis of RA are PADI, CTLA4, PTPN22, CCRS6, CSF2, B3GNT2, PDE2A-ARAP1,

ANXA3, ARID5B, CD83, PLD4, and PTPN2 [22-25].

\section{Environmental factors}

The increase of risk of RA has been substantiated by recent research with certain environmental influences. Smoking and alcohol consumption are the most general risk factor [17]. Long-term smoking associates the increased risk of developing seropositive RA [20]. Some other factors rising the risk of developing RA include high sodium ingestion, autoimmune thyroid disease (AITD), atopic dermatitis (AD), schizophrenia, cigarette smoking, and endometriosis [26-32].

\section{Manifestations associated with Rheumatoid arthritis}

The major manifestations of RA are categorized in to three, which comprise bone, airway and cardiovascular system. In case of bone manifestations, bones are exaggerated both locally and systemically. Local factors that stimulate osteoclasts result in increased bone resorption and have released these osteoclasts from inflammatory and fibroblastic pannus cells [34]. RA patients were usually vulnerable to bisphosphonate treatment for osteoporosis or for the reduction of glucocorticoid-mediated degradation of bone. Airway symptoms of RA include cricoarytenoid arthritis, pulmonary fibrosis and mild airway disorder, usually known as bronchiolitis and disruptive lung function abnormalities. In RA cases, lung disease is the highest mainly in male seropositive smokers. The risk of mortality in RA patients is $40 \%$ higher, leading to an increased incidence of cardiovascular disease with a high level [35]

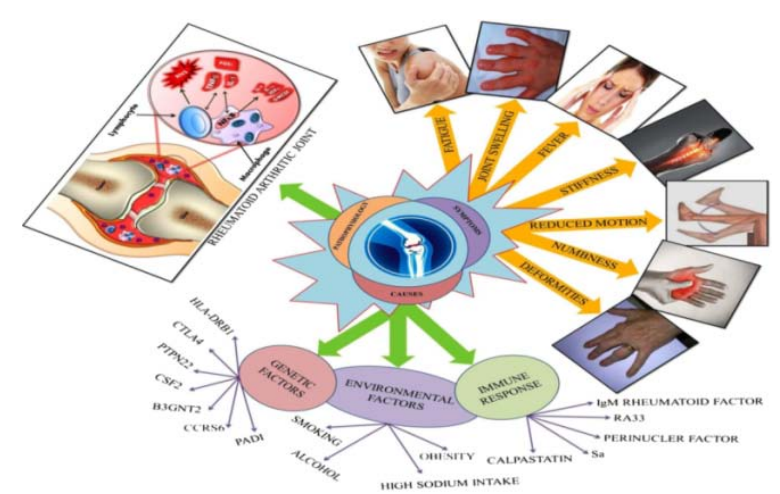

Fig. 3: Factors involved in pathogenesis of rheumatoid arthritis [33]

\section{Treatment options for Rheumatoid arthritis}

Curing RA is still out of our reach at present [36, 37]. Nonsteroidal anti-inflammatory medicines (NSAIDs), glucocorticoids (GCs), disease-modifying anti-rheumatic drugs (DMARDs), and biological agents are the most widely utilized treatment methods $[11,38]$. NSAIDs (such as ibuprofen and celecoxib) could quickly decrease pain and inflammation by inhibiting cyclooxygenases. However, they are no longer considered to be first-line treatments because of their incapacity to stop joint damage and variety of side effects such as gastrointestinal bleeding, renal dysfunction and cardiovascular disease risk. GCs including prednisolone (Pred), dexamethasone (Dex) and budesonide (Bud) include a potent anti-inflammatory ability and are broadly used in treating active RA, while side effects such as immunosuppression, osteoporosis, hyperglycaemia and hypertension associated with the amount cannot be unnoticed while long term therapy. DMARDs such as methotrexate (MTX) can gradually reduce joint damage and control the disease progression. They have been exposed to provide a more approving outcome in patients. In clinical application, a mishmash of several DMARDs or DMARDs with other types of agents has been demonstrated to be beneficial to arthritis remission [39-42]. The development of biotechnology has promoted the expansion of biological agents in RA treatment. This class includes cytokine antagonists (such as infliximab, a TNF- $\alpha$ inhibitor), B-cell depleting agents (such as rituximab), T-cell costimulation modulators (such as abatacept) and kinase inhibitors (such as JAK inhibitors). Even though the high effectiveness in clinical use, nearly $30 \%$ of patients still explain low responsiveness. In addition, diverse problems are associated with current biological therapies, such as elevated costs and risk of serious bacterial infections [36, 38, 39, 43-45]. Despite this narrow clinically used therapeutics in RA, academic research has provided numerous promising therapeutic targets. The components participating in RA incidence and progress, such as diverse cytokines, linkage molecules, proteases and numerous cells including monocytes, FLS, VEC and osteoclasts, might be developed as potential therapeutic targets. In exacting, many endogenous antiinflammatory molecules or cells survive in the human body, for example, anti-inflammatory cytokines (IL-4, IL-10), numerous kinds of microRNA (miR-23b), receptor antagonists, or regulatory T cells (Treg) and M2 type macrophages. In the inflammatory milieu, the balance between usual immune response and inflammatory cascade breaks down. These endogenous anti-inflammatory agents are actually insufficient to counterbalance the huge complicated inflammatory network. Mimicking the action of such natural 
inhibitors or promoting their endogenous production would be promising therapeutic approaches. Non-conventional methods comprise herbal treatment. Herbal medicines have always been in concern to promote health since untimely times. The herbal treatment is now days extremely used as a substitute technique for the treatment of RA. This comes under the term corresponding and alternative approach (CAM). The major common herbs used are ginger, curcumin, Boswellia, C. sinensis, U. tomentosa, U. guianensis, T. wilfordii hook F, Linum usitaissimum, Arctium lappa or Arcticum minus, Urtica dioica, Willow bark, resveratrol, guggulosterone, piperine etc. Herbal treatment offers many advantages such as security, less side effects and gives better outcomes. Along with this, the chiropractic treatment is also extensively used [46]. The different nanoparticulate based delivery system adopted by various drugs is showed in table 2. The implication of nanoparticles based formulation for the treatment of RA may afford enhanced bioavailability, increased gathering of drug at the diseased reddened site and extended discharge characteristics. At the superior level these nanoparticulate based formulation may also elicits target capacity potential with specific receptors. Ayurvedic system is classified into 3 subcategories based on their mental and physical composition, known as Prakriti, which are Pitta, Kapha, and Vata. In India, the doctors usually administer ayurvedic medicines along with allopathic medicines, with a scientific approach. This practice is based primarily on spiritual beliefs, and is secret. Herbal medicines can be taken as antimicrobials, anti-inflammatory and antiviral in RA infections, injury healing and fever. Some of the at present available herbs used for arthritis treatment are enlisted in table 1 [47].

Table 1: Various herbs used in RA

\begin{tabular}{|c|c|c|c|}
\hline S. No. & Plant name & Families and local name & Useful portion \\
\hline 1 & Alpinia galangal Linn & Zingiberaceae, Arattai, Perarattai & Rhizomes \\
\hline 2 & Anacyclus pyrethrum & Asteraceae, Akkirakkaram & Roots \\
\hline 3 & Capparis deciduas & Capparaceae, Senkam, Sirakkali & Roots \\
\hline 4 & Aquilaria agallocha & Thymeleaceae, Krsnaguru & Wood and Oil \\
\hline 5 & Callicarpa macrophylla & Verbenaceae, Nallai & Flowers and fruits \\
\hline 6 & Aphanamixis polystachya & Meliaceae, Malampuluvan & Bark \\
\hline 7 & Argemone Mexicana & Papaveraceae, Kutiyotti & Whole plant, Latex \\
\hline 8 & Ficus benghalensis & Moraceae, Alamaram & Latex \\
\hline 9 & Hygrophila auriculata & Acanthaceae, Nirmulli & Roots, Leaves and Seeds \\
\hline 10 & Fritillaria roylei Hook & Orchidaceae, Kakoli & Bulbs \\
\hline 11 & Heliotropium indicum Linn & Boraginaceae, Telkodukka & Whole plant \\
\hline 12 & Holarrhena pubescens & Apocynaceae, Kutasappalai, & Barks, Seeds and Leaves \\
\hline 13 & Flacourtia jangomas & Flacourtiaceae, Vaiyyankarai & Fruits \\
\hline 14 & Gossypium herbaceum & Malvaceae, Panju & Leaves \\
\hline 15 & Justicia gendarussa Burn & Acanthaceae, Vataikkutti & Roots and Leaves \\
\hline 16 & Mimosa pudica Linn & Mimosaceae, Tottalcurunki & Whole plant \\
\hline 17 & Kaempferia galangal Linn & Zingiberaceae, kaccolam & Rhizomes and Leaves \\
\hline 18 & Lantana camara Linn & Verbenaceae, Arisimalar, Unnicceti & Frutis \\
\hline 19 & Mangifera indica Linn & Anacardiaceae, Mamaram, Mankai & Roots and Barks \\
\hline 20 & Lilium polyphyllum D & Liliaceae, Ksirakakoli & Bulb \\
\hline 21 & Naravelia zeylanica Linn & Ranunculaceae, Vatamkolli & Whole plant \\
\hline 22 & Oroxylum indicum Linn & Bignoniaceae, Palaiyudaycci & Roots \\
\hline 23 & Tribulus terrestris Linn & Zygophyllaceae, Nerinci & Whole Plant \\
\hline 24 & Jasminum lanceolarium & Oleaceae, Makarandam & Leaves and Flowers \\
\hline
\end{tabular}

\section{Problems associated with conventional dosage forms}

The variety of conventional dosage forms obtainable for RA treatment includes tablets, capsules, oral liquids, topical products, parenterals, paediatric/geriatric products, and transdermal patches. Ointment, cream, gels or paste are the topical dosage forms for RA healing. Transdermal patches are topical drug delivery device that spreads drugs non-invasively across the skin. The main drawbacks associated with conventional dosage forms for treating RA were poor compliance with patience, short half-life, low bioavailability and poor solubility, which can be enhanced by customized new dosage forms [48]. The novel dosage form obtainable for RA treatments includes microparticles, nanoparticles, nanoemulsions, nanomicelles, nanodispersions, nanocapsules, nanosuspensions etc.

\section{Nanotechnology}

Nanotechnology deals with the exploitation of issues at nuclear level to generate newer novel nano materials due to its capability to produce sophisticated nanomaterials, processes and products selected at nanoscale, which is creating an added increment over the recent years [49]. Lately many techniques were developed to revise the physical phenomena and constructs (typically 1-100 nanometers) of different nanomaterials [50]. The word "smart materials" was used to describe nanoparticles to target drug delivery to individual body organs. Over the last few years, this technology has shielded its way into expanding the future applications of nanoparticles as beauty products. Liposomal technologies have been used to regulate optical properties to advance their solubility and alter their physical properties, provided for hydrophilic vesicles with phosphatidylcholine membrane(s)
[51]. Nanomaterials have been used in remedial field for beneficial drug delivery with the focus for treatments of diverse diseases/disorders. Micro and nano scale systems can exploit the efficacy of therapeutic treatments in many ways because they paves the capability to quickly notice and react to disease states frankly at the site by improving the patient's quality of life [52].

\section{Nanoparticles for the management of RA}

Nanoparticles are particles in spherical form [39]. Nanoparticles' thickness, surface heterogeneity and morphology play an important role in the biodistribution of nanoparticles for the treatment of RA [53]. Nanoparticles (NPs), for theranostic applications, are used as therapeutic/imaging agents. The encapsulated particulate material aims to provide a controversial distribution/controlled discharge of encapsulated products. Physicochemical properties connected with, Passive targeting of RA treatment drugs includes particle size, shape of the load and characteristics of outside. Nanoparticles in particular take on their vital role in pharmaceutical industries because of their biocompatibility and biodegradability properties. Nanoparticles paired with specific ligand targets and rendered cellular diffusion simpler [54]. The most commonly reported liposomes, micelles, metallic nanoparticles, and polymeric nanoparticle deliver capable of treating RA. By systemic circulation, nanoparticles can be used through various processes such as adsorption, ligand receptor attachment, covalent binding and internalization [55]. NSAID-based delivery systems have been widely documented for RA, which reduces pain (analgesia) related to early stage RA through its antiinflammatory pathways devoid of lack of articular function; however, it inhibits COX-1 and COX-2 enzymes that play a necessary 
role in prostaglandin production. Drug that contains nanoparticles was therapeutically delivered to reddened synovium [39]. Metal oxide nanoparticles show various desirable characteristics, such as drug carriers with extremely higher surface area and large pore sizes for drug encapsulation, intrinsic biodegradability characteristics due to their labile metal-ligand bonds and flexible versatility for post-synthetic drug molecules grafting [56]. Rutin stabilized silver nanoparticles elicits anti-inflammatory involvement in systemic inflammation by its crucial activation of pro- inflammatory cytokine production (tumor necrotic factor- $\alpha$ (TNF- $\alpha$ ) and interleukin-6 (IL-6). In RA patients silver nanoparticles were also used for therapeutic benefits [57]. Table 2 shows the numerous nanoparticulate-based delivery systems used by various medicines. The use of nanoparticle-based formulations in the treatment of RA might result in improved bioavailability, greater drug collection at the affected inflamed site, and longer discharge characteristics. These nanoparticulate-based formulations may also stimulate target capacity potential with particular receptors at a higher level.

Table 2: Nanoparticle based anti-rheumatic arthritic drugs

\begin{tabular}{|c|c|c|c|}
\hline Drugs & Nano carrier & Therapeutic effects & Reference \\
\hline MTX & Gold half shell nanoparticle & Anti-rheumatic arthritic effect & [58] \\
\hline Celecoxib & Solid lipid nanoparticle (Tristearin) & Anti-inflammatory, Anti-rheumatic arthritic effect & [59] \\
\hline $\begin{array}{l}\text { Dexamethasone } \\
\text { and MTX }\end{array}$ & Chitosan Nanoparticles & $\begin{array}{l}\text { Anti-inflammatory, Anti-rheumatic arthritic and } \\
\text { antioxidant potential }\end{array}$ & [60] \\
\hline Curcumin & Carboxy methyl cellulose acetate butyrate (CMCAB) & Anti-rheumatic arthritic effect & [61] \\
\hline MTX & $\begin{array}{l}\text { (Arginine glycine aspartic acid) peptide conjugated gold } \\
\text { shell nanoparticle }\end{array}$ & Anti-inflammatory, Anti-rheumatic arthritic effect & [62] \\
\hline Tacrolimus & Human serum albumin & Anti-rheumatic arthritic effect & [63] \\
\hline
\end{tabular}

\section{Solid lipid nanoparticle for the treatment of RA}

Solid lipid nanoparticles (SLNS) are colloidal carriers with particle size ranging from $120-200 \mathrm{~nm}$, broadly utilized for prohibited drug delivery which merges the benefits of polymeric nanoparticles and oil in water emulsions [64]. SLNs have extraordinary properties such as a good acceptability, protection of incorporated active compounds next to chemical degradation, higher bioavailability with assimilation of both lipophilic and hydrophilic drugs, higher drug loading ability and moderately safe for biological applications [65]. Due to its exclusive size range SLNs hardly undergoes blood clearance by the reticulo endothelial system. SLNs were completed of physiological lipids, fatty acids, phospholipids and mono/di/triglycerides. To make SLNs, a variety of procedures can be utilized, including high shear homogenization, ultrasonic, high pressure homogenization, hot homogenization, cold homogenization, solvent emulsification, and evaporation processes. Lipid-based formulations for enhanced oral bioavailability of poorly water soluble medicines employing SLNs have received more attention in recent years [66]. The drug carrier combines the benefits of polymeric nanoparticles, fat emulsions, and liposomes, including enhanced physical stability, cheap cost, scaleability, and production simplicity [67].

Curcumin-encumbered solid lipid nanoparticles (C-SLNs) for inflammation were created by Arora et al., 2014, to overcome curcumin's low bioavailability [68]. They have an average particle size, product content and capacity of $134 \mathrm{~nm}, 3.78 \mathrm{mg} / \mathrm{ml}$ and $81.92 \%$. They examined how pure curcumin works and C-SLNs in total freund's adjuvant (CFA)-induced arthritic rats. They demonstrated that C-SLNs act as the carrier for the effective delivery of curcumin to patients with RA. They caused C-SLNs to demonstrate their anti-arthritis mechanism through an oxido-inflammatory and immunomodulatory cascade in the model of arthritis induced by CFA. Peng et al., 2016 [69] developed SLNs for the continuous release and transdermal delivery of piroxicam (Pir), as well as highlighting the anti-inflammatory activity of existing SLNs. We found that Pir equipped SLNs had an average $102 \mathrm{~nm}$ particle size with a 0.262 PDI and a+30.21 mV charge.

Their optimized formulation, however, showed that Pir-SLNs were formed spherically with higher trapment efficiency (87 percent). They established that SLNs were the best carrier for encapsulation and continued drug release. By reducing the discharge of inflammatory cytokines, Pir-SLNs illustrated the anti-inflammatory responses at edematous site.

Bhalekar et al., 2017, formulated piperine charged solid lipid nanoparticles (P-SLNs) by melt emulsification method for RA treatment [70]. They set a regular diameter of $128.80 \mathrm{~nm}$, with 78.71 per cent encapsulation and-23.34 mV charge.
In vivo pharmacodynamic studies in complete freund's adjuvant induced arthritic rats exhibited significant reduction of TNF- $\alpha$ in treated rat which might be the mechanism behind the DMARD action of P-SLNs. Raj et al., 2015 [71] formed solid lipid nanoparticles (ACFSLNs) loaded with aceclofenac by injecting glyceryl monostearate as lipid into hydrogels using ultrasonic emulsification technique. They optimized the source of lipid and stirring velocity and defined the average particle size $(189 \mathrm{~nm})$, polydispersity index $(0.162 \mathrm{~nm})$ and zeta potential $(-32.51 \mathrm{mV})$ for optimized solution.

They have a trap skill of about 85 per cent. In vivo tests showed stronger edema reserve with a magnitude of 81 percent after $6 \mathrm{~h}$ compared to basic ACF hydrogel tests. Additionally, optimal SLN size and near interaction with the stratum corneum enhanced product deposition in the skin. Hence, they stressed that ACF-SLNs could have beneficial effects for treatment with RA. Injectable actarit loaded solid lipid nanoparticles (A-SLNs) were created by Ye et al., 2008, as a passive targeted agent for the treatment of RA [72]. In this method, A-SLNs were employed to target the spleen and remove the negative consequences (nephrotoxicity) that came with oral delivery. Their optimal formulation had a dimension of $241 \mathrm{~nm}$ and a charge of- $17.14 \mathrm{mV}$.

Entrapment efficiency and loading for A-SLNs were found to be 50.87 percent and 8.48 percent, respectively. They found that, in 50 per cent propylene glycol solution, the plasma concentration of ASLNs was 1.88 times higher than that of the actarit. By comparison, increasing the efficacy of A-SLNs has increased from 6.31 percent to 16.29 percent in spleen, while the drug's renal delivery is greatly decreased following intravenous administration to mice relative to that of the drug solution.

These findings imply that injectable A-SLNs might be a potential inert targeted therapeutic agent for RA therapy, with condensed dosages, reduced dosing occurrence, and reduced toxicity. Table 3 shows the many SLNs-based delivery systems used to deliver a range of medicines. The use of solid lipid nanoparticles in RA formulations might result in a controlled/sustained discharge pattern with fewer dosage frequencies. These solid lipid-based nanoparticles may potentially be able to improve the bioavailability of encapsulated drugs in the treatment of RA.

\section{Recent advancement for the treatment of RA}

Recently, nanoformulation approaches based on siRNA, peptides and selective approaches were tried for successful treatment of RA.

\section{SiRNA based nanoparticulate systems for the treatment of RA}

The cellular method responsible for silencing of the posttranscription gene that acts on messenger RNA (mRNA) is called RNA interference (RNAi). Silencing achieved with small interfering 
RNA (siRNA) is transient; thus new strategies have been developed and reported for longer lasting silencing. Vectors programmed strategy such as short hairpin RNA (shRNA) may be also used for long-term steady cell silencing approach. Due to the outstanding gene silencing potential of RNAi, it has concerned wide attention in terms of high specificity, important effect, minor side effects and simplicity of synthesis. siRNA has the capacity for silencing a precise gene of interest. The issue linked to naked siRNA after systematic administration was nuclease dilapidation that eventually shortens the circulation period of siRNA in the blood stream. Alternatively,
siRNA is consumed in the endocytosis mediated by the receptor, thereby emerging from the endosomal compartment with reduced naked siRNA therapeutic output. Such concerns have, however, been resolved lately by the production of products focused on nanotechnology. To provide enhanced protection, the siRNA was encapsulated in fully charged particles that effectively protect against serum degradation and immunological effects off-target. Lately siRNA based delivery systems were utilized for the treatment of RA, particularly providing a capable distribution intoperipherally inflamed tissue [13].

Table 3: Solid lipid nanoparticle based anti-rheumatic arthritic drugs

\begin{tabular}{|c|c|c|c|}
\hline Drugs & Nano carrier & Therapeutic effects & Reference \\
\hline Curcumin & Indian Gold & Oxido-inflammatory and immunomodulatory cascade & [68] \\
\hline Piroxicam & Glycerol monostearate & Anti-inflammatory effect & [69] \\
\hline Piperine & Glycerol monostearate & Anti-inflammatory effect & [70] \\
\hline Aceclofenac & Glycerol monostearate & Anti-inflammatory effect & [71] \\
\hline Actarit & Stearic acid & Anti-rheumatic arthritic effect & [72] \\
\hline Apigenin & $\begin{array}{l}\text { Glyceryl monostearate, tocopheryl } \\
\text { polyethylene glycol succinate }\end{array}$ & Anti-rheumatic arthritic effect & [73] \\
\hline Etofenamate and Ibuprofen & Compritol $® 888$ ATO & Anti-inflammatory effect & [74] \\
\hline$\beta$-Sitosterol & Poly (lactic-co-glycolic acid) & Anti-rheumatic arthritic effect & [75] \\
\hline Nabumetone & Compritol 888 ATO & Anti-inflammatory effect & [76] \\
\hline Celecoxib & Glycerol monostearate & Anti-inflammatory effect & [77] \\
\hline $\begin{array}{l}\text { Nabumetone, Ketoprofen, Ibuprofen } \\
\text { and phosphotungstic acid }\end{array}$ & Glycerol monostearate & Anti-inflammatory effect & [64] \\
\hline
\end{tabular}

\section{Targeted nanoparticulate systems for the treatment of RA}

Drug delivery systems can be further enhanced with active targeting ligands such as antibody, peptide, and polysaccharides for their therapeutic efficiency and specificity towards the treatment of various disorders. The two aiming modes were active and passive. In the treatment of RA, thenanoparticulate formulation has been beleaguered towards the selectively expressed CD44 surface receptors. Mediators such as growth factors, pro-inflammatory cytokines, chemokines, cell adhesion molecules, and proteases plays essential role in the RA development. In this plan angiogenesis and inflammation were the conditions connected with RA progression. The macrophages over-expressed the CD44, CD64, folate receptorbeta $(\mathrm{FR}-\beta)$, vasoactive intestinal peptide (VIP) receptor, and scavenger receptor class A, toll-like receptors, transforming factorbeta receptor increases. Whereas $\alpha v \beta 3$ integrins, E-selectin, molecule-1 (VCAM-1) vascular cell adhesion, and molecule-1 intercellular cell adhesion is expressed more under angiogenic conditions [13].

\section{Peptide based nanoparticulate systems for the treatment of RA}

Peptides were lately gaining dedicated interest towards drug delivery for a diversity of therapeutic approaches. Enzymatic proteolysis bioactive peptides derived from natural protein sources (milk, egg, plants, fish, meat etc.) use biological activities for different disorders. Some peptides have the properties of antihypertensive, anti-inflammatory, antidiabetic, anticancer, antimicrobial, and antioxidant. Casein hydrolysate was effective in combating inflammation.

Low bioavailability, metabolic liability, gastrointestinal tract degradation, short absorption, inability to cross epithelial barriers were the problems associated with peptides. To incorporate/assemble the peptides into the nanostructures, solidphase peptide synthesis, ring-opening polymerization and protein engineering methods were used.

Different types of peptides, such as dipeptides, cyclic peptides, amphiphilic peptides,-helical peptides, and-sheet peptides, have been used in nanoparticulate self-assemblies. Peptide-based delivery methods, mostly from natural sources and synthetic peptides, have recently been used to treat RA [13].

\section{Patents for RA treatment by nanoparticles}

Nanotechnologists have been steadily increasing the use of lipidbased nanoparticles as RA treatments. Furthermore, several related patents have garnered wide attention. Table 4 illustrates the recent progression in the field for this purpose [79].

Table 4: Clinical application of nanotherapeutic agents in arthritic diseases

\begin{tabular}{|c|c|c|}
\hline Patent & Lipid nanocarriers & Advantage function \\
\hline US $20150174069 \mathrm{~A} 1$ & Dexamethasone sodium phosphate liposome & There is a $10 \%$ decrease in one or more of the symptoms of arthritis \\
\hline WO 2003000190 A2 & Glycosaminoglycans liposome & It has a high level of effectiveness in the treatment of osteoarthritis \\
\hline CN $104688721 \mathrm{~A}$ & Paclitaxel liposome & The gel has a therapeutic effect and relieves pain in RA patients \\
\hline US $20090232731 \mathrm{~A} 1$ & Cationic liposome & $\begin{array}{l}\text { It helps to reduce mononuclear cell infiltration into synovial tissue, } \\
\text { pannus formation, and cartilage degradation }\end{array}$ \\
\hline US 20160000714 & Curcumin solid lipid particles & It provides suppression of cyclooxygenase 2 (COX-2) expression \\
\hline WO 2017025588 A1 & Cyclosporine solid lipid particles & $\begin{array}{l}\text { It inhibits interleukin } 2 \text { transcription, lowering } \mathrm{T} \text { lymphocyte activation } \\
\text { and proliferation }\end{array}$ \\
\hline US 8715736 & B2 Nanostructured Lipid Carriers & In RA, it allows for effective skin penetration at the inflammatory site \\
\hline CN 102225205 B & Tripterine nanostructured lipid carrier & It reduces the inflammation associated with rheumatoid arthritis \\
\hline
\end{tabular}

\section{Methotrexate}

Methotrexate (2,4-diamino-N10-methyl propylglutamic acid, MTX) is one of the major widely studied and effective therapeutics agents accessible to treat many solid tumors, hematologic malignancies, and autoimmune diseases [82]. MTX has played a critical role in the treatment of breast cancer, acute lymphatic leukemia (ALL), osteogenic sarcoma, choriocarcinoma, lung cancer, bladder 
carcinoma, brain medulloblastoma, primary CNS lymphoma, and chronic myeloid leukemia $[80,81]$. Apart from its original usage as a cancer chemotherapeutic agent, it is now used to treat psoriasis, multiple sclerosis, Crohn's disease, and rheumatoid arthritis, among other illnesses. The Food and Drug Administration (FDA) approved the use of MTX in the treatment of rheumatoid arthritis in 1988, and it is currently regarded the gold standard medication [82-86]. MTX, 2,4-diamino-N10-methyl propylglutamic acid, was first synthesized by Seeger et al., $60 \mathrm{y}$ ago. It is a folic acid analog in which the groups bonded to the $\mathrm{C} 4$ carbon and $\mathrm{N} 10$ hydrogen are $\mathrm{NH} 2$ and $\mathrm{CH} 3$. There are three parts in its structure as follows: (1) pteridine ring, (2) paminobenzoic acid, and (3) glutamic acid. It is a weak bicarboxylic acid among a molecular weight of $454.5 \mathrm{~g} / \mathrm{mol}\left(\mathrm{C}_{20} \mathrm{H}_{22} \mathrm{~N}_{8} \mathrm{O}_{5}\right)$. The drug possess pKa values of $3.8,4.8$, and 5.6 and low permeability ( $\log \mathrm{P}=0.53)$ [87]. The solubility of MTX in distilled water at $20^{\circ} \mathrm{C}$ is $0.01 \mathrm{mg} / \mathrm{ml}$ and is $\mathrm{pH}$-dependent. This chemical is easily degraded by heat and light. The degradation of MTX solution is $\mathrm{pH}$-dependent and catalyzed mostly by buffer chemicals in a common acid-base reaction. For greatest MTX persistence, a pH range of 6.6-8.2 is recommended [88]. MTX works as a cancer chemotherapeutic drug by inhibiting dihydrofolate reductase (DHFR) with high similarity, resulting in a decrease in tetrahydrofolates, which are required for purine and thymidilate production. As a result, DNA and RNA synthesis, as well as other metabolic processes, are disrupted [89]. However, MTX does not operate primarily as an antiproliferative drug for the cells responsible for rheumatoid arthritis coupled inflammation. The quick clinical remission seen with low dosage MTX combined with a rapid flare of illness upon medication cessation implies that low dose MTX's mechanism of action is more anti-inflammatory than antiproliferative $[89,90]$. In fact, MTX inhibits both dihydrofolate reductase and other folate-dependent enzymes and leads to adenosine overproduction which can induce immunosuppression [91].

\section{Pathophysiogical approaches for delivery of MTX}

Numerous unique characteristics and pathophysiological phenomena of cancers and rheumatoid arthritis can be used as targets or tools for drug delivery, such as angiogenesis [91, 92], improved permeability and retention (EPR) effects [93-95], tissue hypoxia and acidosis [96], and expression of specific antigens and receptors [97-99], and addition of inflammatory cells such as macrophages and T lymphocytes. Angiogenesis not only is necessary for primary tumor growth but also facilitates tumor incursion and metastasis. Tumor microvascular networks have several single pathophysiological features distinguishing them from vigorous blood vessels. These contain extremely dense populations of leaky, tortuous, and primitive microvessels with pericyte covering, basement membrane, and arteriole-venule differences. Rapid angiogenesis leads to high vascular solidity in tumor and inflammatory tissues with great gaps survive between endothelial cells in blood vessels, so tumor, and inflammatory tissues show choosy extravasations of macromolecules compared with normal tissues. Dissimilar the situation with tumor and inflammatory tissues, approval of macromolecules from the interstitial space of normal tissues proceed quickly and gradually via the lymphatic system. Macromolecule clearance in the tumor and inflammatory interstitium is so poor that they stay there for a long period. These phenomena are usually termed EPR effects. On the other hand, because to inadequate blood perfusion, high interstitial fluid pressure, acidosis, and the rapid development of malignant tissues, these peculiar characteristics frequently produce a hypoxic environment. In twist, tissue hypoxia leads to configuration of new imperfect blood vessels. Polymeric conjugates, such as human serum albumin, liposomal conjugates, microspheres, solid lipid nanoparticles, in situ forming hydrogels, polymeric nanoparticles, dendrimers, such as polyamidoamine, polymeric micelles, magnetic nanoparticles, and carrier erythrocyte have all been developed to overcome the drawbacks of MTX therapy. For active targeting, some are further modified with targeting ligands.

\section{Nanoparticles}

MTX-loaded polymeric nanoparticles, arranged either by physical entrapment or chemical conjugation were broadly studied to attain sustained discharge pattern, to enhance chemo sensitivity of tumor cell lines or to aim cells/tissues by polymer coating (e. g. Tween 80 ) or ligand conjugation (e. g. folic acid, LHRH, biotin). Taheri et al. prepared MTX-HSA conjugates by carbodiimide reaction. The conjugates were cross-linked with 1-ethyl-3-(3dimethylaminopropyl) carbodiimide (EDC) to form steady nanoparticles with the mean sizes of 90-150 nm. The nanoparticles were exposed to be more cytotoxic on T47D cells compared to free of charge MTX. Moreover, MTX-HSA nanoparticles decreased the IC50 value of MTX on T47D cells in assessment with free MTX [100]. MTXHSA nanoparticles (MTX-HSA NPs) were coupled with luteinizing-hormone-releasing hormone (LHRH) and used to target 4T1 breast cancer cells in another investigation. In vivo investigations in Balb/c mice bearing 4T1 breast cancer tumors revealed that following a single IV injection of free MTX, nontargeted MTX-HAS NPs, and LHRH targeted MTX-HSA NPs, LHRH targeted MTX-HSA NPs demonstrated greater anti-tumor action. The average tumor volume in the LHRH targeted MTX-HSA NPs-treated animals had dropped to $8.67 \%$ of the initial tumor volume by $7 \mathrm{~d}$ following treatment, whereas the average tumor volume in nontargeted MTX-HSA NPs-treated mice had grown fast and reached $250.7 \%$ of the initial tumor volume $[101,102]$. Similarly, biotin was taken as targeting agent. By $7 \mathrm{~d}$ after single IV injection in the mice model, average tumor volume in the biotin targeted MTX-HSA NPstreated group decreased to $17.6 \%$ of the initial tumor volume. Biotin targeted MTX-HSA NPs improved the survival of tumor bearing mice and increased their life span $[103,104]$. Trastuzumab (TMAB) adorned MTX-HSA NPs were made in another research. It has been demonstrated that precise targeting of TMAB-MTX-HSA nanoparticles can improve MTX therapeutic effectiveness on HER2 tumor cells while reducing MTX adverse effects [105]. Jain et al. used a reverse microemulsion technique to make MTX-loaded HSA NPs, which were then chemically crosslinked with glutaraldehyde and FA conjugated through a PEG spacer. In vitro, it was discovered that these NPs specifically target folate-receptor overexpressing cancer cells, killing them via S-phase arrest. Circulation duration and tumor-specific localisation of MTX loaded HSA NPs increased after polyethylene glycolylation and conjugation with FA. When compared to non-targeted controls, HSA NPs suppressed tumor development more effectively [106]. Trapani et al. used an ionic gelation technique using sodium tripolyphosphate (TPP) to make MTX-loaded chitosan (CS) or glycol chitosan (GCS) nanoparticles for brain administration in the presence and absence of a Tween 80 coating layer. The smallest mean size $(125 \mathrm{~nm})$ was reported for MTX-loaded GCS/Tween 80 NPs even as they were about $255 \mathrm{~nm}$ for MTX-loaded CS and CS/Tween 80 NPs [107]. In alike study by Azadi et al., minimum mean size of $60 \mathrm{~nm}$ with $62 \%$ loading competence was reported. The most cytotoxic NPs against the C6 glioma cell line were GCS-based NPs. Confocal observations revealed that Tween 80coated fluorescent NPs internalized more than untreated NPs [108]. Ji et al. created MTX-loaded CS covalently linked with FA, with TPP as the cross-linking agent, to reduce the toxicity of methotrexate (MTX) and increase the targeting capacity of NPs. The nanoparticles' typical sizes varied from 300 to $400 \mathrm{~nm}$. In phosphate-buffer saline (pH 6.8), the discharge pattern revealed that MTX-loaded nanoparticles exhibited an early burst effect followed by a slow sustained drug release [109]. In another research, MTX was loaded into FA-conjugated O-carboxymethyl chitosan (FA-OCMC) NPs through a crosslinking process between the carboxyl groups of 0 $\mathrm{CMC}$ and $\mathrm{Ca} 2$ ions. The FA-O-CMC nanoparticles had a better encapsulation competence and MTX loading capacity than the FA-CS NPs, while the FA-O-CMC nanoparticles had a smaller particle size. Furthermore, it was discovered that while the initial release of MTX from FA-OCMC nanoparticles was slower, the cumulative release was considerably larger than that of FA-CS nanoparticles [109]. By scattering polymerization (DP) and emulsion polymerization (EP) of n-butyl cyanoacrylate monomer, Reddy et al. created poly (butylcyanoacrylate) NPs. In comparison to the DP approach, the EP method produced smaller particles. With increasing monomer concentrations, both kinds of NPs showed an increase in drug entrapment. In $0.1 \mathrm{~mol} / \mathrm{l} \mathrm{HCl}$, MTX release from DP and EP nanoparticles followed Fickian diffusion, while the technique was shown to be anomalous in phosphate buffer (pH 7.4) [110]. In another work, Gao et al. used a mixed polymerization technique to make polybutylcyanoacrylate NPs coated with polysorbate 80 for 
brain administration. Rats were given nanoparticles with diameters of $70,170,220$, and $345 \mathrm{~nm}$ by IV injection. It was observed that as compared to uncoated nanoparticles, covered nanoparticles may improve drug point in both brain tissues and cerebrospinal fluids and were a simple solution. Seventy-nanometer nanoparticles may carry more medicines into the brain, but the other three size ranges showed no differences [111]. Cascone et al. used a simple solvent evaporation process based on a single water-in-oil emulsion and stabilized with glutaraldehyde as a cross-linking agent to produce gelatin nanoparticles with initial different quantities of MTX. The particles were able to discharge MTX via a diffusion-controlled mechanism that was unaffected by the quantity of MTX loaded in the range of 5-15 percent [112].

\section{Future perspectives for the treatment of RA}

Natural treatments such as physical therapy, clinical therapy, and psychosocial treatment are currently important for promoting the recovery of autoimmune inflammatory RA diseases. While combinatorial therapies have a better solution, the selectivity and toxicity features of the healthy cells pose a major problem.

Potential treatment options for RA treatment separately from nanoparticulate formulations that rely on the production of proinflammatory cytokine specific inhibitors through virtue applications of monoclonal antibodies, bioactive peptides, and siRNAbased delivery systems. Leaning focusing on molecular biology and computational chemistry may offer a better suggestion for developing formulations intended to target pro-inflammatory cytokines.

\section{CONCLUSION}

RA is a pathogenic autoimmune disease that causes bone erosion deformation, and even physical disability. While the traditional drug formulation would provide an appropriate solution in RA, no single drug therapy or combination therapy has been satisfactorily concluded with serious systemic side effects, frequent administration, tolerance from long-lasting management and high costs. Also with the newer biological therapeutics, there is a need to get better their side effect. To address these issues, extensive attention has been given to the concept of nanoparticles as drug carriers to improve the therapeutic index of drugs. Most of the current studies show improved efficacy when administering a drug in the formulation of nanoparticles as compared to the free drug, mostly in three aspects: selective accumulation, prohibited drug release and condensed systemic toxicity. The newly developed nanocarriers considerably improve the therapeutic effectiveness of present drugs for enhanced RA in experimental models by on the whole dose reduction and higher local drug localization by passive and active drug targeting. Lipid-based nanoparticles are extra advantageous compared to other nanoparticles because of the extra biocompatible and biodegradable nature of their constituents relative to the synthetic polymers establish in other types of nanoparticles. Currently, a multiplicity of lipid-based nanoparticles encapsulated with drugs is clinically approved and commercially obtainable, while lots of more formulations are being investigated in dissimilar stages of clinical trials or are awaiting approval. However, added studies are still necessary to optimize their capability as drugdelivery systems. Lipid-based nanoparticles have the potential to boost anti-arthritic drug effectiveness and safety profile and, more importantly, the result for patients with RA.

\section{FUNDING}

Nil

\section{AUTHORS CONTRIBUTIONS}

All authors have contributed equally.

\section{CONFLICT OF INTERESTS}

Declared none

\section{REFERENCES}

1. Aletaha D, Neogi T, Silman AJ, Funovits J, Felson DT, Bingham CO, Birnbaum NS, Burmester GR, Bykerk VP, Cohen MD, Combe B, Costenbader KH, Dougados M, Emery P, Ferraccioli G, Hazes JM,
Hobbs K, Huizinga TW, Kavanaugh A, Kay J, Kvien TK, Laing T, Mease P, Menard HA, Moreland LW, Naden RL, Pincus T, Smolen JS, Stanislawska-Biernat E, Symmons D, Tak PP, Upchurch KS, Vencovsky J, Wolfe F, Hawker G. 2010 rheumatoid arthritis classification criteria: an American college of Rheumatology/European league against rheumatism collaborative initiative. Arthritis Rheum. 2010;62(9):2569-81. doi: 10.1002/art.27584, PMID 20872595.

2. Symmons DP. Epidemiology of rheumatoid arthritis: determinants of onset, persistence and outcome. Best Pract Res Clin Rheumatol. 2002;16(5):707-22. doi: 10.1053/berh.2002.0257, PMID 12473269.

3. Dorner T, Strand V, Cornes P, Gonçalves J, Gulacsi L, Kay J, Kvien TK, Smolen J, Tanaka Y, Burmester GR. The changing landscape of biosimilars in rheumatology. Ann Rheum Dis. 2016;75(6):974-82. doi: 10.1136/annrheumdis-2016-209166, PMID 26964144.

4. Gibofsky A. Overview of epidemiology, pathophysiology, and diagnosis of rheumatoid arthritis. Am J Manag Care. 2012;18(13);Suppl:S295-302. PMID 23327517.

5. Handa R, Rao UR, Lewis JF, Rambhad G, Shiff S, Ghia CJ. Literature review of rheumatoid arthritis in India. Int J Rheum Dis. 2016;19(5):440-51. doi: 10.1111/1756-185X.12621, PMID 26171649.

6. Crielaard BJ, Lammers T, Schiffelers RM, Storm G. Drug targeting systems for inflammatory disease: one for all, all for one. J Control Release. 2012;161(2):225-34. doi: 10.1016/j.jconrel.2011.12.014, PMID 22226771.

7. Grassi W, De Angelis R, Lamanna G, Cervini C. The clinical features of rheumatoid arthritis. Eur J Radiol. 1998;27;Suppl 1:S18-24. doi: 10.1016/s0720-048x(98)00038-2, PMID 9652497.

8. Kanazawa T, Nishino J, Tohma S, Tanaka S. Analysis of the affected joints in rheumatoid arthritis patients in a large Japanese cohort. Mod Rheumatol. 2013;23(1):44-9. doi: 10.1007/s10165-012-0636-7, PMID 22466118.

9. Pfizer. Pfizer value of medicines, Rheumatoid Arthritis and the Value of Treatment Global Policy and International Public Affairs; 2014. Available from: https://www.com/ files/health/VOMPaper_RheumatoidArthritis_11-3-2016.pdf. [Last accessed on 10 Jul 2021]

10. Svendsen AJ, Junker P, Houen G, Kyvik KO, Nielsen C, Skytthe A, Holst R. Incidence of chronic persistent rheumatoid arthritis and the impact of smoking: A historical twin cohort study. Arthritis Care Res. 2017;69(5):616-24. doi: 10.1002/acr.22987, PMID 27390149.

11. Yang $M$, Feng X, Ding J, Chang F, Chen X. Nanotherapeutics relieve rheumatoid arthritis. J Control Release. 2017;252:10824. doi: 10.1016/j.jconrel.2017.02.032, PMID 28257989

12. McInnes IB, Schett G. Pathogenetic insights from the treatment of rheumatoid arthritis. Lancet. 2017;389(10086):2328-37. doi: 10.1016/S0140-6736(17)31472-1, PMID 28612747.

13. Janakiraman $\mathrm{K}$, Krishnaswami $\mathrm{V}$, Rajendran $\mathrm{V}$, Natesan $\mathrm{S}$, Kandasamy R. Novel nano therapeutic materials for the effective treatment of rheumatoid arthritis-recent insights. Mater Today Commun. 2018;17:200-13. doi: 10.1016/j.mtcomm.2018.09.011, PMID 32289062. mtcomm.2018.09.011.

14. Montecucco F, Mach F. Common inflammatory mediators orchestrate pathophysiological processes in rheumatoid arthritis and atherosclerosis. Rheumatology (Oxford). 2009;48(1):11-22. doi: 10.1093/rheumatology/ken395, PMID 18927189 .

15. Deane KD, Norris JM, Holers VM. Preclinical rheumatoid arthritis: identification, evaluation, and future directions for investigation. Rheum Dis Clin North Am. 2010;36(2):213-41. doi: 10.1016/j.rdc.2010.02.001, PMID 20510231.

16. Silman AJ, Pearson JE. Epidemiology and genetics of rheumatoid arthritis. Arthritis Res. 2002;4(3);Suppl 3:S265-72. doi: 10.1186/ar578, PMID 12110146.

17. Liao KP, Alfredsson L, Karlson EW. Environmental influences on risk for rheumatoid arthritis. Curr Opin Rheumatol. 2009;21(3):279-83. doi: 10.1097/BOR.0b013e32832a2e16, PMID 19318947.

18. Deane KD, El-Gabalawy H. Pathogenesis and prevention of rheumatic disease: focus on preclinical RA and SLE. Nat Rev 
Rheumatol. 2014;10(4):212-28. doi: 10.1038/nrrheum.2014.6, PMID 24514912.

19. Aletaha D, F Alasti, JS Smolen. Rheumatoid factor, not antibodies against citrullinated proteins, is associated with baseline disease activity in rheumatoid arthritis clinical trials. Arthritis Res Ther. 2015;17(1):229. doi: 10.1186/s13075-015-0736-9.

20. C Edwards, C Cooper. Early environmental factors and rheumatoid arthritis. Clin Exp Immunol. 2006;143(1):1-5. doi: 10.1111/j.1365-2249.2005.02940.x, PMID 16367927.

21. J Newton JL, S Harney SM, B Wordsworth BP, M Brown MA. A review of the MHC genetics of rheumatoid arthritis. Genes Immun. 2004;5(3):151-7. doi: 10.1038/sj.gene.6364045, PMID 14749714.

22. A Suzuki, R Yamada, $X$ Chang, $S$ Tokuhiro, T Sawada, M Suzuki, M Nagasaki, M Nakayama-Hamada, R Kawaida, M Ono, Ohtsuki M, Furukawa H, Yoshino S, Yukioka M, Tohma S, Matsubara T, Wakitani S, Teshima R, Nishioka Y, Sekine A, Iida A, Takahashi A, Tsunoda T, Nakamura Y, Yamamoto K. Functional haplotypes of PADI4, encoding citrullinating enzyme peptidylarginine deiminase 4 , are associated with rheumatoid arthritis. Nat Genet. 2003;34(4):395-402. doi: 10.1038/ng1206, PMID 12833157.

23. RM Plenge, L Padyukov, EF Remmers, S Purcell, AT Lee, EW Karlson, F Wolfe, DL Kastner, L Alfredsson, D Altshuler, Gregersen PK, Klareskog L, Rioux JD. Replication of putative candidate-gene associations with rheumatoid arthritis in $>4,000$ samples from North America and Sweden: association of susceptibility with PTPN22, CTLA4, and PADI4. Am J Hum Genet. 2005;77(6):1044-60. doi: 10.1086/498651, PMID 16380915.

24. Y Kochi, Y Okada, A Suzuki, K Ikari, C Terao, A Takahashi, K Yamazaki, N Hosono, K Myouzen, T Tsunoda, Kamatani N, Furuichi T, Ikegawa S, Ohmura K, Mimori T, Matsuda F, Iwamoto T, Momohara S, Yamanaka H, Yamada R, Kubo M, Nakamura Y, Yamamoto K. A regulatory variant in CCR6 is associated with rheumatoid arthritis susceptibility. Nat Genet. 2010;42(6):515-9. doi: 10.1038/ng.583, PMID 20453841.

25. Y Okada, C Terao, K Ikari, Y Kochi, K Ohmura, A Suzuki, T Kawaguchi, EA Stahl, FA Kurreeman, N Nishida, Ohmiya H, Myouzen K, Takahashi M, Sawada T, Nishioka Y, Yukioka M, Matsubara T, Wakitani S, Teshima R, Tohma S, Takasugi K, Shimada K, Murasawa A, Honjo S, Matsuo K, Tanaka H, Tajima K, Suzuki T, Iwamoto T, Kawamura Y, Tanii H, Okazaki Y, Sasaki T, Gregersen PK, Padyukov L, Worthington J, Siminovitch KA, Lathrop M, Taniguchi A, Takahashi A, Tokunaga K, Kubo M, Nakamura Y, Kamatani N, Mimori T, Plenge RM, Yamanaka H, Momohara S, Yamada R, Matsuda F, Yamamoto K. Metaanalysis identifies nine new loci associated with rheumatoid arthritis in the Japanese population. Nat Genet. 2012;44(5):511-6. doi: 10.1038/ng.2231, PMID 22446963.

26. E Salgado, M Bes-Rastrollo, J de Irala, L Carmona, JJ Goomez Reino. High sodium intake is associated with self-reported rheumatoid arthritis: a cross sectional and case control analysis within the SUN cohort. Medicine (Baltimore) 2015;94(37):e0924. doi: 10.1097/MD.0000000000000924, PMID 26376372.

27. I Lazurova, I Jochmanova, K Benhatchi, S Sotak. Autoimmune thyroid disease and rheumatoid arthritis: relationship and the role of genetics. Immunol Res. 2014;60 :193-200. doi: 10.1007/s12026-014-8598-9, PMID 25427993.

28. J Schmitt, K Schwarz, H Baurecht, M Hotze, R Folster Holst, E Rodriguez, YA Lee, A Franke, F Degenhardt, W Lieb, Gieger C, Kabesch M, Nothen MM, Irvine AD, McLean WHI, Deckert S, Stephan V, Schwarz P, Aringer M, Novak N, Weidinger S. Atopic dermatitis is associated with an increased risk for rheumatoid arthritis and inflammatory bowel disease, and a decreased risk for type 1 diabetes. J Allergy Clin Immunol. 2016;137(1):130-6. doi: 10.1016/j.jaci.2015.06.029, PMID 26253344.

29. RJ Oken, M Schulzer. At issue: schizophrenia and rheumatoid arthritis: the negative association revisited. Schizophr Bull. 1999;25(4):625-38. 10.1093/oxfordjournals.schbul.a033407, PMID 10667736.

30. P Stolt, C Bengtsson, B Nordmark, S Lindblad, I Lundberg, L Klareskog, L Alfredsson, EIRA Study Group. Quantification of the influence of cigarette smoking on rheumatoid arthritis: results from a population based case-control study, using incident cases. Ann Rheum Dis. 2003;62(9):835-41. doi: 10.1136/ard.62.9.835, PMID 12922955

31. JE Hart, F Laden, RC Puett, KH Costenbader, EW Karlson Exposure to traffic pollution and increased risk of rheumatoid arthritis. Environ Health Perspect. 2009;117(7):1065-9. doi: 10.1289/ehp.0800503, PMID 19654914.

32. HR Harris, KH Costenbader, F Mu, M Kvaskoff, S Malspeis, EW Karlson, SA Missmer. Endometriosis and the risks of systemic lupus erythematosus and rheumatoid arthritis in the Nurses' Health Study II. Ann Rheum Dis. 2016;75(7):1279-84. doi: 10.1136/annrheumdis-2015-207704, PMID 26238146.

33. Sourav Thakur S, Bushra Riyaz B, Akshay Patil A, Amanjot Kaur A, Bhupinder Kapoor B, Vijay Mishra V. Novel drug delivery systems for NSAIDs in management of rheumatoid arthritis: Aan overview. Biomed Pharmacother. 2018;106:1011-23. doi: 10.1016/j.biopha.2018.07.027, PMID 30119166.

34. CT Kraft, S Agarwal, K Ranganathan, VW Wong, S Loder, J Li J, MJ Delano, B Levi. Trauma-induced heterotopic bone formation and the role of the immune system: A review. J Trauma Acute Care Surg. 2016;80(1):156-65. doi: 10.1097/ TA.0000000000000883, PMID 26491794.

35. G Jones, P Nash, S Hall. Advances in rheumatoid arthritis. Med J Aust. 2017;206(5):221-4. doi: 10.5694/mja16.01287, PMID 28301793.

36. MI Koenders, WB van den Berg. Novel therapeutic targets in rheumatoid arthritis. Trends Pharmacol Sci. 2015;36(4):189-95.

37. F Yuan, LD Quan, L Cui, SR Goldring, D Wang. Development of macromolecular prodrug for rheumatoid arthritis. Adv Drug Delivery Rev. 2012;64(12):1205-19. doi: 10.1016/j.addr.2012.03.006, PMID 22433784.

38. Van Vollenhoven RF. Treatment of rheumatoid arthritis: state of the art. Nat Rev Rheumatol. 2009;5(10):531-41. doi: 10.1038/nrrheum.2009.182, PMID 19798027.

39. Dolati S, Sadreddini S, Rostamzadeh D, Ahmadi M, Jadidi Niaragh F, Yousefi M. Utilization of nanoparticle technology in rheumatoid arthritis treatment. Biomed Pharmacother. 2016;80:30-41. doi: 10.1016/j.biopha.2016.03.004, PMID 27133037.

40. Tarner IH, Muller Ladner U. Drug delivery systems for the treatment of rheumatoid arthritis. Expert Opin Drug Deliv. 2008;5(9):1027-37. doi: 10.1517/17425247.5.9.1027, PMID 18754751.

41. Prasad LK, O'Mary H, Cui Z. Nanomedicine delivers promising treatments for rheumatoid arthritis. Nanomedicine (Lond). 2015;10(13):2063-74. doi: 10.2217/nnm.15.45, PMID 26084368.

42. Mitragotri S, Yoo JW. Designing micro- and nano-particles for treating rheumatoid arthritis. Arch Pharm Res. 2011;34(11):1887-97. doi: 10.1007/s12272-011-1109-9.

43. Buch MH, Bingham SJ, Bryer D, Emery P. Long-term infliximab treatment in rheumatoid arthritis: subsequent outcome of initial responders. Rheumatology (Oxford). 2007;46(7):1153-6. doi: 10.1093/rheumatology/kem075, PMID 17478470.

44. Chaudhari K, Rizvi S, Syed BA. Rheumatoid arthritis: current and future trends. Nat Rev Drug Discov. 2016;15(5):305-6. doi: 10.1038/nrd.2016.21, PMID 27080040.

45. Listing J, Strangfeld A, Kary S, Rau R, Von Hinueber U, Stoyanova Scholz M, Gromnica Ihle E, Antoni C, Herzer P, Kekow J, Schneider M, Zink A. Infections in patients with rheumatoid arthritis treated with biologic agents. Arthritis Rheum. 2005;52(11):3403-12. doi: 10.1002/art.21386, PMID 16255017.

46. Rao JK, Mihaliak K, Kroenke K, Bradley J, Tierney WM, Weinberger M. Use of complementary therapies for arthritis among patients of rheumatologists. Ann Intern Med. 1999;131(6):409-16. doi: 10.7326/0003-4819-131-6199909210-00003, PMID 10498556.

47. Chandrasekar R, Chandrasekar S. Natural herbal treatment for rheumatoid arthritis-a review. Int J Pharm Sci Res. 2017;8(2):368.

48. Movahedi M, Beauchamp ME, Abrahamowicz M, Ray DW, Michaud K, Pedro S, Dixon WG. Risk of incident diabetes mellitus associated with the dosage and duration of oral glucocorticoid therapy in patients with rheumatoid arthritis. Arthritis Rheumatol. 2016;68(5):1089-98. doi: 10.1002/art.39537, PMID 26663814. 
49. Bahadar H, Maqbool F, Niaz K, Abdollahi M. Toxicity of nanoparticles and an overview of current experimental models. Iran Biomed J. 2016;20(1):1-11. doi: 10.7508/ibj.2016.01.001, PMID 26286636.

50. Xu L, Qi X, Li X, Bai Y, Liu H. Recent advances in applications of nanomaterials for sample preparation. Talanta 2016;146:714-26.

51. Y Panahi, M Farshbaf, M Mohammadhosseini, M Mirahadi, R Khalilov, S Saghfi, A Akbarzadeh. Recent advances on liposomal nanoparticles: synthesis, characterization and biomedical applications. Artif Cells Nanomed Biotechnol. 2017;45(4):78899. doi: 10.1080/21691401.2017.1282496, PMID 28278586.

52. Heloise R, Danhier F, Preat V, Langer R, Anderson DG. Nanoparticle-based drug delivery systems: a commercial and regulatory outlook as the field matures. Expert Opion Drug Delivery 2017;14(7):851-64.

53. E Nogueira, AC Gomes, A Preto, A Cavaco, Paulo A. Folatetargeted nanoparticles for rheumatoid arthritis therapy. Nanomedicine 2016;12(4):1113-26. doi: 10.1016/ j.nano.2015.12.365, PMID 26733257.

54. Q Thao le, Byeon HJ, Lee C, Lee S, Lee ES, Choi HG, Park ES, Youn YS le, HJ Byeon C. Pharmaceutical potential of tacrolimusloaded albumin nanoparticles having targetability to rheumatoid arthritis tissues. Int J Pharm 2016;497(1-2):26876. doi: 10.1016/j.ijpharm.2015.12.004, PMID 26657273.

55. S Behzadi, V Serpooshan, W Tao, MA Hamaly, MY Alkawareek, EC Dreaden, D Brown, AM Alkilany, OC Farokhzad, M Mahmoudi. Cellular uptake of nanoparticles: Journey inside the cell. Chem Soc Rev. 2017;46(14):4218-44. doi: 10.1039/c6cs00636a, PMID 28585944.

56. TM Ahmed, BM Aljaeid. Preparation, characterization, and potential application of chitosan, chitosan derivatives, and chitosan metal nanoparticles in pharmaceutical drug delivery. Drug Des Dev Ther. 2016;10:483-507. doi: 10.2147/DDDT.S99651, PMID 26869768.

57. Rao SD. Rheumatoid arthritis (ra) disease treatment with rutin stabilized nanoparticles, Austin. J Biotechnol Bioeng. 2015; 2(2):1043.

58. Lee SN, Kim HJ, Ha YJ, Park YN, Lee SK, Park YB, Yoo KH. Targeted chemophotothermal treatments of rheumatoid arthritis using gold half-shell multifunctional nanoparticles. ACS. 2012;7(1):50-7.

59. Kishore N, Raja MD, Kumar CS, Dhanalekshmi U, Srinivasan R. Lipid carriers for delivery of celecoxib: in vitro, in vivo assessment of nanomedicine in rheumatoid arthritis. Eur J Lipid Sci Technol. 2016;118(6):949-58. doi: 10.1002/ejlt.201400658.

60. Kumar V, Leekha A, Tyagi A, Kaul A, Mishra AK, Verma AK. Preparation and evaluation of biopolymeric nanoparticles as drug delivery system in effective treatment of rheumatoid arthritis. Pharm Res. 2017;34(3):654-67. doi: 10.1007/s11095016-2094-y, PMID 28097508.

61. Dewangan AK, Varkey S, Mazumder S. Synthesis of curcumin loaded $\mathrm{CMCAB}$ nanoparticles for the treatment of rheumatoid arthritis, IJCEBS; 2015. p. 18-9.

62. Lee SM, Kim HJ, Ha YJ, Park YN, Lee SK, Park YB, Yoo KH. Targeted chemo-photothermal treatments of rheumatoid arthritis using gold half-shell multifunctional nanoparticles. ACS Nano. 2013;7(1):50-7. doi: 10.1021/nn301215q, PMID 23194301.

63. Thao le Q, Byeon HJ, Lee C, Lee S, Lee ES, Choi HG, Park ES, Youn YS. Pharmaceutical potential of tacrolimus-loaded albumin nanoparticles having targetability to rheumatoid arthritis tissues. Int J Pharm. 2016;497(1-2):268-76. doi: 10.1016/j.ijpharm.2015.12.004, PMID 26657273.

64. Kumar R, Singh A, Garg N, Siril PF. Solid lipid nanoparticles for the controlled delivery of poorly water soluble non-steroidal anti-inflammatory drugs. Ultrason Sonochem. 2018;40(A):68696. doi: 10.1016/j.ultsonch.2017.08.018, PMID 28946474.

65. Geszke Moritz M, Moritz M. Solid lipid nanoparticles as attractive drug vehicles: composition, properties and therapeutic strategies. Mater Sci Eng C Mater Biol Appl. 2016;68:982-94. doi: 10.1016/j.msec.2016.05.119, PMID 27524099.

66. Garg NK, Singh B, Tyagi RK, Sharma G, Katare OP. Effective transdermal delivery of methotrexate through nanostructured lipid carriers in an experimentally induced arthritis model. Colloids Surf B Biointerfaces. 2016;147:17-24. doi: 10.1016/j.colsurfb.2016.07.046, PMID 27478959.

67. Chavan D, Gangode B, Jadhav A, Patil M, Kshirsagar S. Solid lipid nanoparticles: A modern formulation approach in drug delivery system. IJOD. 2017;5(2):56-70.

68. Arora R, Kuhad A, Kaur IP, Chopra K. Curcumin loaded solid lipid nanoparticles ameliorate adjuvant-induced arthritis in rats. Eur J Pain. 2015;19(7):940-52. doi: 10.1002/ejp.620, PMID 25400173.

69. Peng LH, Wei W, Shan YH, Chong YS, Yu L, Gao JQ. Sustained release of piroxicam from solid lipid nanoparticle as an effective antiinflammatory therapeutics in vivo. Drug Dev Ind Pharm. 2017;43(1):55-66. doi: 10.1080/03639045.2016.1220563. PMID 27498809.

70. Bhalekar MR, Madgulkar AR, Desale PS, Marium G. Formulation of piperine solid lipid nanoparticles (SLN) for treatment of rheumatoid arthritis. Drug Dev Ind Pharm. 2017;43(6):100310. doi: 10.1080/03639045.2017.1291666, PMID 28161984.

71. Raj R, Mongia P, Ram A, Jain NK. Enhanced skin delivery of aceclofenac via hydrogel-based solid lipid nanoparticles. Artif Cells Nanomed Biotechnol. 2016;44(6):1434-9. doi: 10.3109/21691401.2015.1036997, PMID 25919063.

72. Ye J, Wang Q, Zhou X, Zhang N. Injectable actarit-loaded solid lipid nanoparticles as passive targeting therapeutic agents for rheumatoid arthritis. Int J Pharm 2008;352(1-2):273-9. doi: 10.1016/j.ijpharm.2007.10.014, PMID 18054182.

73. Gilani SJ, Bin-Jumah MN, Imam SS, Alshehri S, Jahangir MA Zafar A. Formulation and optimization of nano lipid based oral delivery systems for arthritis. Coatings. 2021;11(5):548. doi: 10.3390/coatings11050548.

74. Mancini G, Gonçalves LMD, Marto J, Carvalho FA, Simoes S, Ribeiro HM, Almeida AJ. Increased therapeutic efficacy of SLN containing etofenamate and ibuprofen in topical treatment of inflammation. Pharmaceutics. 2021;13(3):328. doi 10.3390/pharmaceutics13030328, PMID 33802592

75. Zhang F, Liu Z, He X, Li Z, Shi B, Cai F. $\beta$-sitosterol-loaded solid lipid nanoparticles ameliorate complete freund's adjuvantinduced arthritis in rats: involvement of NF- $\mathrm{KB}$ and $\mathrm{HO}-1 / \mathrm{Nrf}-2$ pathway. Drug Deliv. 2020;27(1):1329-41. doi: 10.1080/10717544.2020.1818883, PMID 32945205.

76. Chaudhari PM, Ghodake MV. Development and optimization of solid lipid nanoparticle for topical delivery. J Drug Deliv Ther. 2019;9(5):105-21.

77. Shinde SV, Nikam S, Raut P, Ghag MK. Lipid nanoparticles for transdermal delivery of celecoxib: an in vitro and in vivo investigation. Indian Drugs. 2019;56(8):38-48.

78. Chuang SY, Lin CH, Huang TH, Fang JY. Lipid-based nanoparticles as a potential delivery approach in the treatment of rheumatoid arthritis. Nanomaterials (Basel). 2018;8(1):42. doi: 10.3390/nano8010042, PMID 29342965.

79. Purcell WT, Ettinger DS. Novel antifolate drugs. Curr Oncol Rep. 2003;5(2):114-25. doi: 10.1007/s11912-003-0098-3, PMID 12583828.

80. Bleyer WA. The clinical pharmacology of methotrexate: new applications of an old drug. Cancer. 1978;41(1):36-51. doi: 10.1002/1097-0142(197801)41:1<36:aidcncr2820410108>3.0.co;2-i, PMID 342086.

81. Grim J, Chladek J, Martínkova J. Pharmacokinetics and pharmacodynamics of methotrexate in non-neoplastic diseases. Clin Pharmacokinet. 2003;42(2):139-51. doi: 10.2165/00003088-200342020-00003, PMID 12537514.

82. Cutolo M, Sulli A, Pizzorni C, Seriolo B, Straub RH. Antiinflammatory mechanisms of methotrexate in rheumatoid arthritis. Ann Rheum Dis. 2001;60(8):729-35. doi: 10.1136/ard.60.8.729, PMID 11454634.

83. Lee DM, Weinblatt ME. Rheumatoid arthritis. Lancet. 2001;358(9285):903-11. doi: 10.1016/S0140-6736(01)060755, PMID 11567728.

84. Tarner IH, Muller Ladner U. Drug delivery systems for the treatment of rheumatoid arthritis. Expert Opin Drug Deliv. 2008;5(9):1027-37. doi: 10.1517/17425247.5.9.1027, PMID 18754751.

85. Rahman LK, Chhabra SR. The chemistry of methotrexate and its analogues. Med Res Rev. 1988;8(1):95-155. doi: 10.1002/med.2610080106, PMID 3278183. 
86. Chatterji DC, Gallelli JF. Thermal and photolytic decomposition of methotrexate in aqueous solutions. J Pharm Sci. 1978;67(4):52631. doi: 10.1002/jps.2600670422, PMID 641762.

87. Genestier L, Paillot R, Quemeneur L, Izeradjene K, Revillard JP. Mechanisms of action of methotrexate. Immunopharmacology. 2000;47(2-3):247-57. doi: 10.1016/s0162-3109(00)00189-2, PMID 10878292.

88. Cutolo M, Bisso A, Sulli A, Felli L, Briata M, Pizzorni C, Villaggio B. Antiproliferative and antiinflammatory effects of methotrexate on cultured differentiating myeloid monocytic cells (THP-1) but not on synovial macrophages from patients with rheumatoid arthritis. J Rheumatol. 2000;27(11):2551-7. PMID 11093433.

89. Hillson JL, Furst DE. Pharmacology and pharmacokinetics of methotrexate in rheumatic disease. Practical issues in treatment and design. Rheum Dis Clin North Am. 1997;23(4):757-78. doi: 10.1016/s0889-857x(05)70359-8, PMID 9361154.

90. Cronstein BN. The mechanism of action of methotrexate. Rheum Dis Clin North Am. 1997;23(4):739-55. doi: 10.1016/S0889-857X(05)70358-6.

91. Koch AE, Distler O. Vasculopathy and disordered angiogenesis in selected rheumatic diseases: rheumatoid arthritis and systemic sclerosis. Arthritis Res Ther. 2007;9 Suppl 2:S3. doi: 10.1186/ar2187, PMID 17767741

92. Koning GA, Schiffelers RM, Wauben MH, Kok RJ, Mastrobattista E, Molema G, ten Hagen TL, Storm G. Targeting of angiogenic endothelial cells at sites of inflammation by dexamethasone phosphate-containing RGD peptide liposomes inhibits experimental arthritis. Arthritis Rheum. 2006;54(4):1198-208. doi: 10.1002/art.21719, PMID 16575845.

93. Gaffo A, Saag KG, Curtis JR. Treatment of rheumatoid arthritis. Am J Health Syst Pharm. 2006;63(24):2451-65. doi: 10.2146/ajhp050514, PMID 17158693

94. Levick JR. Permeability of rheumatoid and normal human synovium to specific plasma proteins. Arthritis Rheum. 1981;24(12):1550-60. doi: 10.1002/art.1780241215, PMID 7326067.

95. Levick JR. Microvascular architecture and exchange in synovial joints. Microcirculation. 1995;2(3):217-33. doi: 10.3109/10739689509146768, PMID 8748946.

96. Levick JR. Hypoxia and acidosis in chronic inflammatory arthritis; relation to vascular supply and dynamic effusion pressure. J Rheumatol. 1990;17(5):579-82. PMID 2359066.

97. Halin C, Neri D. Antibody-based targeting of angiogenesis. Crit Rev Ther Drug Carrier Syst. 2001;18(3):299-339. doi: 10.1615/CritRevTherDrugCarrierSyst.v18.i3.20, PMID 11442202.

98. Nagai T, Tanaka M, Tsuneyoshi Y, Matsushita K, Sunahara N, Matsuda T, Yoshida H, Komiya S, Onda M, Matsuyama T. In vitro and in vivo efficacy of a recombinant immunotoxin against folate receptor beta on the activation and proliferation of rheumatoid arthritis synovial cells. Arthritis Rheum. 2006;54(10):3126-34. doi: 10.1002/art.22082, PMID 17009233.

99. Trachsel E, Bootz F, Silacci M, Kaspar M, Kosmehl H, Neri D. Antibody-mediated delivery of IL-10 inhibits the progression of established collagen-induced arthritis. Arthritis Res Ther. 2007;9(1):R9. doi: 10.1186/ar2115, PMID 17261171.

100. Taheri A. Nanoparticles of conjugated methotrexate-human serum albumin: preparation and cytotoxicity evaluations. J Nanomaterials 2011;5:1-7. doi: 10.1155/2011/768201

101. Taheri A, Dinarvand R, Ahadi F, Khorramizadeh MR, Atyabi F. The in vivo antitumor activity of LHRH targeted methotrexate- human serum albumin nanoparticles in 4T1 tumor-bearing Balb/c mice. Int J Pharm. 2012;431(1-2):183-9. doi: 10.1016/j.ijpharm.2012.04.033. PMID 22531853.

102. Taheri A, Dinarvand R, Atyabi F, Ahadi F, Nouri FS, Ghahremani MH, Ostad SN, Borougeni AT, Mansoori P. Enhanced antitumoral activity of methotrexate-human serum albumin conjugated nanoparticles by targeting with luteinizing hormone-releasing hormone (LHRH) peptide. Int J Mol Sci. 2011;12(7):4591-608. doi: 10.3390/ijms12074591, PMID 21845098.

103. Taheri A, Dinarvand R, Atyabi F, Nouri F, Ahadi F, Ghahremani MH, Ostad SN, Borougeni AT, Mansoori P. Targeted delivery of methotrexate to tumor cells using biotin functionalized methotrexate-human serum albumin conjugated nanoparticles. J Biomed Nanotechnol. 2011;7(6):743-53. doi: 10.1166/jbn.2011.1340, PMID 22416572.

104. Taheri A, Dinarvand R, Nouri FS, Khorramizadeh MR Borougeni AT, Mansoori P, Atyabi F. Use of biotin targeted methotrexate-human serum albumin conjugated nanoparticles to enhance methotrexate antitumor efficacy. Int J Nanomed. 2011;6:1863-74. doi: 10.2147/IJN.S23949, PMID 21931482.

105. Taheri A, Dinarvand R, Atyabi F, Ghahremani MH, Ostad SN. Trastuzumab decorated methotrexate-human serum albumin conjugated nanoparticles for targeted delivery to HER2 positive tumor cells. Eur J Pharm Sci. 2012;47(2):331-40. doi: 10.1016/j.ejps.2012.06.016, PMID 22771547.

106. Jain S, Mathur R, Das M, Swarnakar NK, Mishra AK. Synthesis, pharmacoscintigraphic evaluation and antitumor efficacy of methotrexate-loaded, folate-conjugated, stealth albumin nanoparticles. Nanomedicine (Lond). 2011;6(10):1733-54. doi: 10.2217/nnm.11.53, PMID 22087800.

107. Trapani A, Denora N, Iacobellis G, Sitterberg J, Bakowsky U, Kissel T. Methotrexate-loaded chitosan- and glycolchitosanbased nanoparticles: a promising strategy for the administration of the anticancer drug to brain tumors. AAPS PharmSciTech. 2011;12(4):1302-11. doi: 10.1208/s12249011-9695-x

108. Azadi A, Hamidi M, Khoshayand MR, Amini M, Rouini MR Preparation and optimization of surface-treated methotrexateloaded nanogels intended for brain delivery. Carbohydrate Polym. 2012;90(1):462-71. 10.1016/j.carbpol.2012.05.066, PMID 24751066.

109. Ji JG, Wu D, Liu L, Chen J, Xu Y. Preparation, characterization, and in vitro release of folic acid-conjugated chitosan nanoparticles loaded with methotrexate for targeted delivery. Polym Bull. 2012;68(6): 1707-20. doi: 10.1007/s00289-0110674-x.

110. Reddy LH, Murthy RR. Influence of polymerization technique and experimental variables on the particle properties and release kinetics of methotrexate from poly(butylcyanoacrylate) nanoparticles. Acta Pharmaceutica. 2004;54(2):103-18. PMID 15274754.

111. Gao K, Jiang X. Influence of particle size on transport of methotrexate across blood brain barrier by polysorbate 80 coated polybutylcyanoacrylate nanoparticles. Int J Pharm. 2006;310(1-2):213-9. doi: 10.1016/j.ijpharm.2005.11.040, PMID 16426779.

112. Cascone MG, Lazzeri L, Carmignani C, Zhu Z. Gelatin nanoparticles produced by a simple W/O emulsion as delivery system for methotrexate. J Mater Sci Mater Med. 2002;13(5):523-6. doi: 10.1023/a:1014791327253, PMID 15348607. 